University of Nebraska - Lincoln

DigitalCommons@University of Nebraska - Lincoln

Publications, Agencies and Staff of the U.S.

Department of Commerce

U.S. Department of Commerce

$7-2003$

\title{
Killer Whale Predation on Belugas in Cook Inlet, Alaska: Implications for a Depleted Population
}

\author{
Kim Shelden \\ National Marine Mammal Laboratory, Alaska Fisheries Science Center, National Marine Fisheries Service, \\ NOAA \\ David J. Rugh \\ National Marine Mammal Laboratory, Alaska Fisheries Science Center, National Marine Fisheries Service, \\ NOAA \\ Barbara Mahoney \\ Alaska Regional Office, National Marine Fisheries Service, NOAA, 222 W. 7th Avenue, Box 43, Anchorage, \\ Alaska \\ Marilyn Dahlheim \\ National Marine Mammal Laboratory, Alaska Fisheries Science Center, NMFS, NOAA
}

Follow this and additional works at: https://digitalcommons.unl.edu/usdeptcommercepub

Part of the Environmental Sciences Commons

Shelden, Kim; Rugh, David J.; Mahoney, Barbara; and Dahlheim, Marilyn, "Killer Whale Predation on Belugas in Cook Inlet, Alaska: Implications for a Depleted Population" (2003). Publications, Agencies and Staff of the U.S. Department of Commerce. 171.

https://digitalcommons.unl.edu/usdeptcommercepub/171

This Article is brought to you for free and open access by the U.S. Department of Commerce at DigitalCommons@University of Nebraska - Lincoln. It has been accepted for inclusion in Publications, Agencies and Staff of the U.S. Department of Commerce by an authorized administrator of DigitalCommons@University of Nebraska - Lincoln. 


\title{
KILLER WHALE PREDATION ON BELUGAS IN COOK INLET, ALASKA: IMPLICATIONS FOR A DEPLETED POPULATION
}

\author{
KIM E. W. SHELDEN \\ David J. Rugh \\ National Marine Mammal Laboratory, \\ Alaska Fisheries Science Center, \\ National Marine Fisheries Service, NOAA, \\ 7600 Sand Point Way NE, \\ Seattle, Washington 98115 , U.S.A. \\ Barbara A. MaHONEY \\ Alaska Regional Office, \\ National Marine Fisheries Service, NOAA, \\ 222 W. 7th Avenue, Box 43, \\ Anchorage, Alaska 99513, U.S.A. \\ Marityn E. Dahliheim \\ National Marine Mammal Laboratory, \\ Alaska Fisheries Science Center, NMFS, NOAA, \\ 7600 Sand Point Way NE, \\ Seartie, Washington 98115, U.S.A.
}

\begin{abstract}
Killer whale predation on belugas in Cook Inlet, Alaska, has become a concern since the decline of these belugas was documented during the 1990s. Accordingly, killer whale sightings were compiled from systematic surveys, observer databases, and anecdotal accounts. Killer whales have been relatively common in lower Cook Inlet (at least 100 sightings from 1975 to 2002), but in the upper Inlet, north of Kalgin Island, sightings were infrequent (18 in $27 \mathrm{yr}$ ), especially prior to the 1990s. Beach cast beluga carcasses with teeth marks and missing flesh also provided evidence of killer whale predation. Most observed killer whale/beluga interactions were in the upper Inlet. During 11 of 15 observed interactions, belugas were obviously injured or killed, either through direct attacks or indirectly as a result of stranding. Assuming at least one beluga mortality occurred during the other four encounters, we can account for 21 belugas killed between 1985 and 2002. This would suggest a minimum estimate of roughly $1 / \mathrm{yr}$ and does not include at least three instances where beluga calves accompanied an adult that was attacked.
\end{abstract}

Key words: Delphinapterus leucas, Orcinus orca, beluga, killer whale, predator-prey interactions, stranding, mortality, Cook Inlet, Alaska. 
A small, genetically distinct population of belugas (Delpbinapterus leucas) inhabits the waters of Cook Inlet (O'Corry-Crowe et al. 1997, Rugh et al. 2000). During the first four years of thorough, systematic aerial surveys in Cook Inlet (1994-1998), the population declined by about $50 \%$ ( 653 whales, CV $=0.43$ in 1994 to 347, $\mathrm{CV}=0.29$ in 1998; Hobbs et al. 2000), during which time there was unregulated hunting by local natives (Mahoney and Shelden 2000). Since then there has been a very limited, regulated hunt, and the population decline has stopped (Hobbs et al. 2000 ). Because the whale population is so small and isolated, there is concern about all sources of mortality for this depleted stock and, in particular, predation by killer whales (Orinus orca) (NMFS 2000).

Killer whale predation of belugas has been observed in arctic and subarctic waters of Greenland (Tomilin 1957, Heide-Jørgensen 1988), Canada (Sergeant and Brodie 1969, Reeves and Mitchell 1988), Russia (Sleptsov 1952 as cited in Kleinenberg et al. 1964), and western Alaska (Lowry et al. 1987, Frost et al. 1992, George and Suydam 1998). ${ }^{1}$ Belugas and killer whales have inhabited Cook Inlet waters since prehistoric times. In lower Cook Inlet (defined here as south of Kenai, or about $60^{\circ} 33^{\prime} \mathrm{N}$ ), in Tuxedni and Kachemak bays, rock paintings 1,000-3,000 yr old depict both of these species (Osgood 1937, deLaguna 1975, Klein 1981). Whale bones have also been found in middens in Native villages along Kachemak Bay circa 625-860 A.D. (Lobdell 1980). Although few of the bones could be identified to species, Lobdell (1980) concluded that "many of the vertebrae were quite small and likely represent the most common whale seen in Kachemak Bay, the beluga." According to a Tanaina Indian interviewed in 1931, the killer whale was common in the lower Inlet, but was not eaten (Osgood 1937).

Killer whales are cosmopolitan, and in Alaskan waters they are widely distributed south of sea ice in the Chukchi Sea (Braham and Dahlheim 1982, Leatherwood et al. 1982). These whales generally occur in small pods, rarely with more than 40 individuals (Dahlheim and Heyning 1998). Although sometimes reported in the open ocean, killer whales are most abundant within $800 \mathrm{~km}$ of the continent (Heyning and Dahlheim 1988). For south-central Alaska, Matkin et al. (1999) indicated there were as many as 291 photographically identified whales in the Prince William Sound/Kenai Fjords region, some of which also range into Cook Inlet. Two sympatric, non-associating types of killer whales inhabit this region: resident whales that feed exclusively on fish, and transients that consume only marine mammals (Saulitis et al. 2000). Of the 291 identified whales in south-central Alaska, 54 are thought to be transients (Matkin et al. 1999). The occurrence of these transient whales is considered rare in southeast Alaska (Dahlheim et al. 1997), thus we assume that most transients found in Prince William Sound/Kenai Fjords range to the west, not to the east. Only four whales identified in Prince William Sound have been also identified in southeast Alaska (Matkin et al. 1999). Transients may have a very extensive range, for instance some were documented to have traveled 2,660 km from southeast Alaska to central California (Goley and Straley 1994). Also, we (M. Dahlheim) have recent photographic matches that show the same transients on the

\footnotetext{
${ }^{\prime}$ Burns, J. J., and G. A. Seaman. 1985. Investigations of belukha whales in coastal waters of western and northern Alaska. II. biology and ecology. Final report. U.S. Department of Commerce, NOAA, Outer Continental Shelf Assessment Program NA 81 RAC 00049. Alaska Department of Fish and Game, Fairbanks. 129 pp.
} 
south side of the Kenai Peninsula and in the Bering Sea $(1,060 \mathrm{~km}$ on a straight line, without allowing for land features).

Although only about 30 killer whale sightings (including many possible resightings) were reported from the southeastern Bering Sea between 1976 and 1990 (Lowry et al. 1987, Frost et al. 1992), five of these were associated with belugas or involved in evident attacks. The distribution of belugas may, in part, be an adaptation to avoid killer whale predation (Sergeant and Brodie 1969), ${ }^{2}$ as has been suggested for the evolution of migration in baleen whales (Corkeron and Connor 1999). Cook Inlet, a semi-enclosed tidal estuary that is seasonally ice-covered, appears to be an environment ideal for evading killer whales. Although some killer whales, such as those in the Crozet Archipelago south of Africa, have been observed intentionally stranding themselves for brief periods on steep, wave-washed beaches when in pursuit of pinnipeds (e.g., Guinet and Bouvier 1995), killer whales are vulnerable to unintentional stranding for extensive periods when they enter shallow, complex mudflats (Frost et al. 1992). In the northern portions of Cook Inlet dramatic tidal changes across extensive mudflats as much as $10 \mathrm{~km}$ across could provide some protection from killer whales. This may be one of the primary reasons that belugas are common there but relatively scarce in the southern parts of Cook Inlet where there are fewer apparent limitations to killer whale movements. During summer months, belugas congregate in the upper reaches of Cook Inlet in shallow water near major river outflows (Moore et al. 2000, Rugh et al. 2000), areas where prey availability is high and predator occurrence relatively low. In winter belugas are found in the upper or central parts of Cook Inlet (Rugh et al. 2000) in areas ranging from ice-free to 60\% ice-covered (Hansen and Hubbard 1999) or even denser ice (Mahoney, personal observation). Murray (1979) ${ }^{3}$ concluded that killer whale predation on belugas in Cook Inlet was minimal given that belugas appeared to be spatially separated from killer whales. We present here the first assessment of killer whale predation on belugas in Cook Inlet.

\section{MeTHODS}

Records of killer whale sightings within Cook Inlet in the past $27 \mathrm{yr}(1975-$ 2002) were obtained from a number of sources, including systematic surveys and anecdotal accounts.

\section{Systematic Surveys}

Seabird and marine mammal surveys have been conducted frequently in different seasons and different parts of Cook Inlet. Aerial surveys to determine abundance and distribution of belugas occurred during the summers of 1964-1965, ${ }^{4}$

\footnotetext{
${ }^{2}$ Lowry, L. F. 1985. The belukha whale (Delphinapterus leucas). Pages 3-13 in J. J. Burns, K. J. Frost and L. F. Lowry, eds. Marine mammals species accounts. Alaska Department of Fish and Game, Game Technical Bulletin No. 7.96 pp.

${ }^{3}$ Murray, N. 1979. Belukha whales in lower Cook Inlet. Environmental Assessment of the Alaskan Continental Shelf, U.S. Department of Commerce, NOAA-ERL-AR-79-1:192-208.

${ }^{4}$ Klinkhart, E. G. 1966. The beluga whale in Alaska. Federal Aid in Wildlife Restoration Project Report Volume VII: Projects W-6-R and W-14-R. Alaska Department of Fish and Game, Juneau, AK. $11 \mathrm{pp}$.
} 
1974-1979 (Calkins 1983), ${ }^{5} 1982-1983,{ }^{6}$ and 1993-2000 (Rugh et al. 2000). In 1997 winter surveys for belugas in ice-free areas of Cook Inler were conducted from mid-February to mid-March (Hansen and Hubbard 1999). Aerial line transect surveys for harbor porpoise (Pbocoena phocoena) were conducted 1-2 August 1991 (Dahlheim et al. 2000). Vessel surveys of seabirds and marine mammals in lower Cook Inlet, south of Kalgin Island, occurred in the summer of 1993 and winter of 1994 (Agler et al. 1995) and in late July to early August of 1995-1999 (Speckman and Piatt 2000).

\section{Anecdotal Reports}

In addition to the marine mammal sightings reported during dedicated surveys (listed above), the National Marine Mammal Laboratory (NMML) maintains a database of marine mammal observations collected opportunistically (National Oceanic and Atmospheric Administration (NOAA) and U.S. Coast Guard personnel, fisheries observers, fisheries personnel, ferry operators, tourists, or other private boat operators). The Platforms of Opportunity Program (POP) database, with sightings dating since 1958, was reviewed for killer whale observations.

Separate from the POP collection at NMML, the National Marine Fisheries Services' (NMFS) Alaska Regional Office has collected anecdotal accounts of marine mammal sightings and strandings in Alaska since 1988. Sources include reports from fishing vessels, charter boat operators, aircraft pilots, NMFS enforcement officers, NMFS scientists, and the general public. Killer whales are relatively easy to identify, so these records can be used reliably.

\section{Pod Size and Photo-identification}

Photographs taken of killer whales during encounters with belugas were reviewed for possible matches in existing photographic catalogs (e.g., Dahlheim 1997, Matkin et al. 1999). In instances where photographs were not available or could not be matched, pod type (resident $v$ s. transient) was determined based on association with other marine mammals, pod size, saddle patch patterns, and/or dorsal fin shape (Bigg et al. 1987, Bain 1989, Baird 2000).

\section{Results}

\section{Systematic Surveys}

Killer whale sightings were not reported during aerial surveys for belugas conducted prior to the $1990 \mathrm{~s}^{3,4,6}$ However, several systematic surveys conducted in the 1990s reported at least one sighting of killer whales. Each June or July of 19932000 , NMFS aerial surveys searched for belugas over nearly $25 \%$ of the total water surface of Cook Inlet and almost $100 \%$ of the coastal areas (Rugh et al. 2000). Although the survey effort was focused on the upper Inlet, only two sightings of

\footnotetext{
${ }^{5}$ Murray, N. K., and F. H. Fay. 1979. The white whales or belukhas, Delpbinapterus leucas, of Cook Inlet, Alaska. Paper SC/31/SM12 presented to the Sub-committee on Small Cetaceans of the Scientific Committee of the International Whaling Commission. Unpublished. 7 pp. Available from AFSC, NMML Library, 7600 Sand Point Way N.E., Seattle, WA 98115.

${ }^{6}$ Calkins, D. G. 1984. Belukha whale. Vol. IX of Susitna hydroelectric project; final report; big game studies. Alaska Department of Fish and Game Doc. 2328. 17 PP.
} 




Figure 1. Sightings of killer whales in Cook Inlet, Alaska, from 1975 to 2002. Systematic surveys, Platforms of Opportunity Program data, and anecdotal accounts are shown as circles, squares, and triangles, respectively. Filled symbols indicate that belugas were present.

killer whales were made during this project, both in the lower Inlet (Fig. 1). No killer whales were seen during $1,873 \mathrm{~km}$ of aerial surveys for harbor porpoise in Cook Inlet in August 1991 (Dahlheim et al. 2000; NMFS, unpublished data). During vessel surveys of the lower Inlet, covering $17,452 \mathrm{~km}^{2}$, observers reported killer whales on three occasions: one in the summer of 1993 and two in the winter of 1994 (Agler et al. 1995). Similar vessel surveys in 1995-1999, covering 6,249 km of trackline (Speckman and Piatt 2000), encountered only three killer whale pods in lower Cook Inlet. During $9,406 \mathrm{~km}$ of aerial surveys in the winter of 1997 , no killer whales were seen in Cook Inlet (Hansen and Hubbard 1999). In summary, during various extensive systematic surveys through the $1990 \mathrm{~s}$, few killer whale sightings $(n=8)$ occurred in Cook Inlet, all of which were in the lower Inler (Fig. 1).

\section{Anecdotal Reports}

In the POP database, there were 15 killer whale sightings reported in Cook Inlet between 1975 and 1999 (Fig. 1). Only one of these sightings occurred in the upper Inler: five whales seen near Anchorage in May 1982 (Table 1).

Most of the killer whale sightings and all records of interactions between killer whales and belugas (99 of 122 reports) came through the NMFS network for 


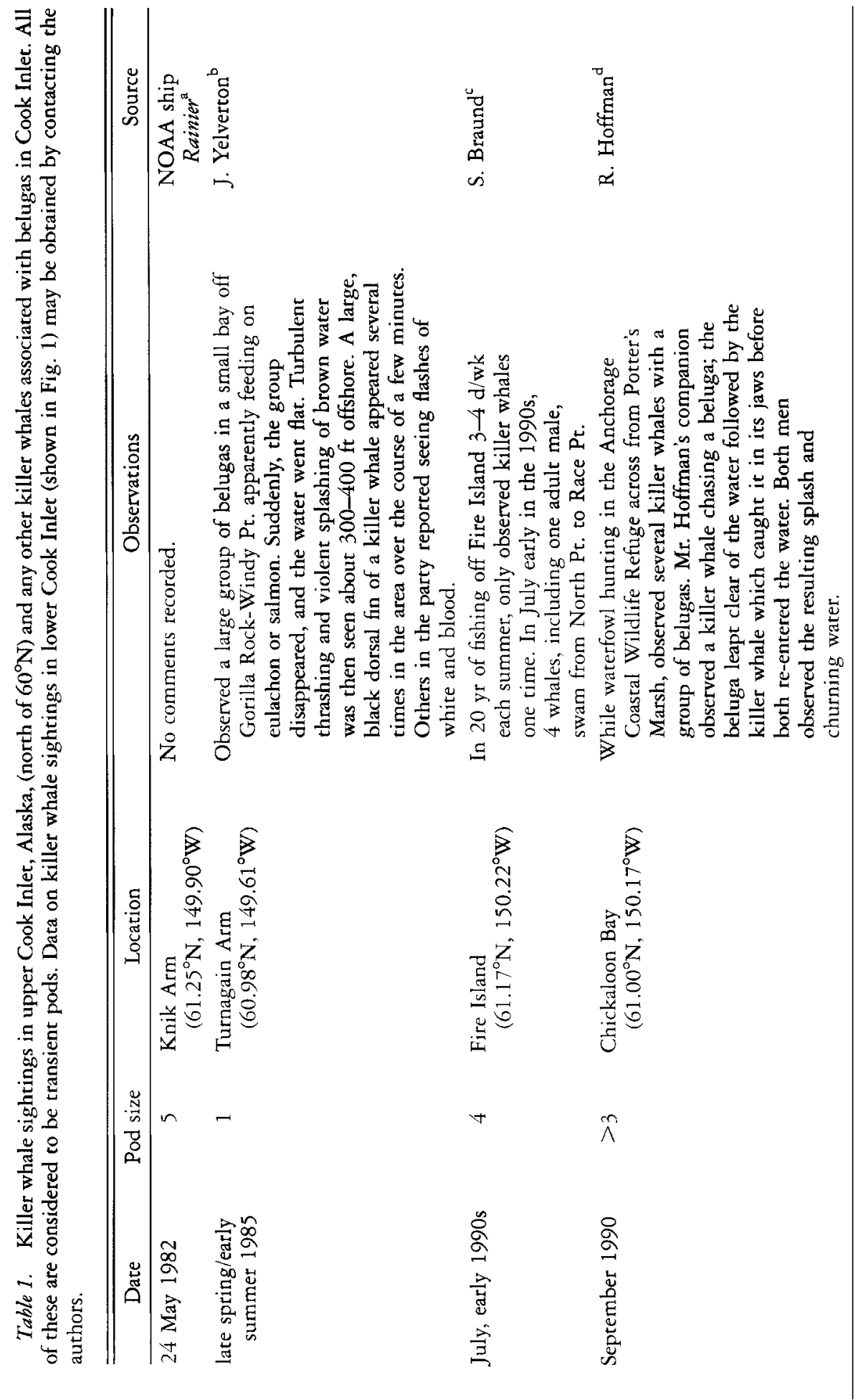




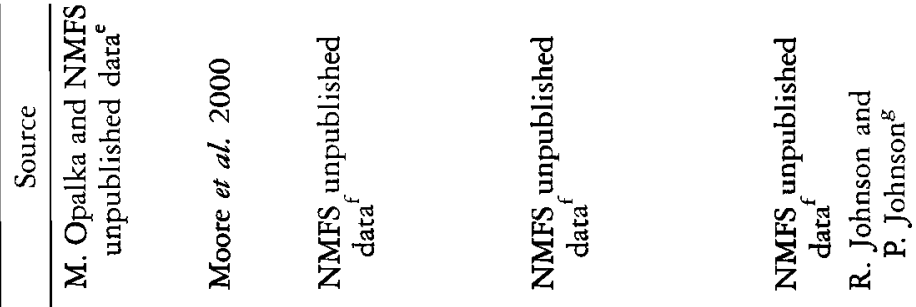

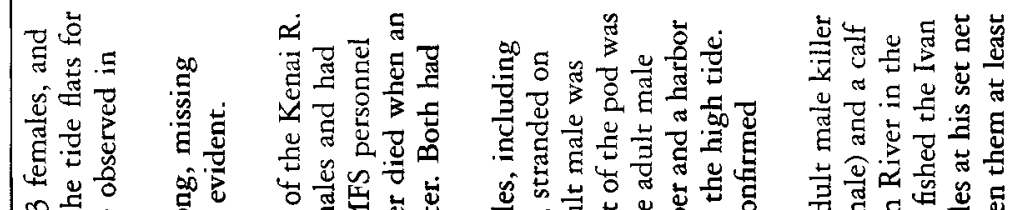

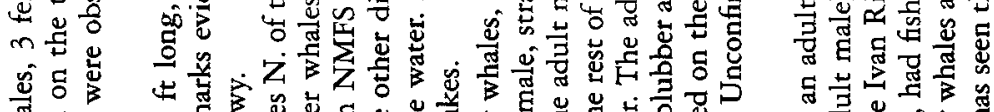

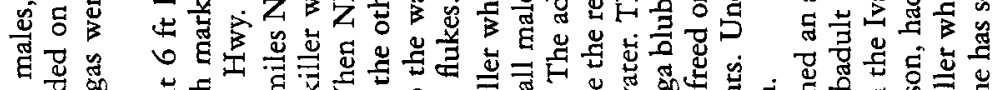

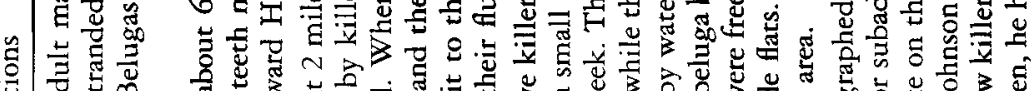

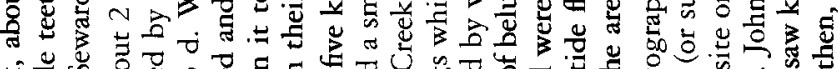

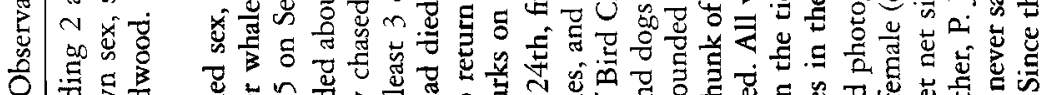

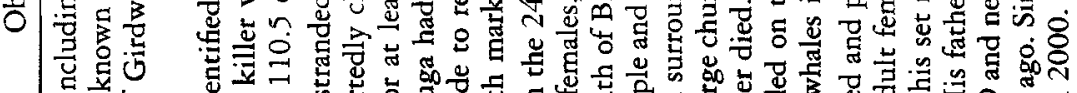

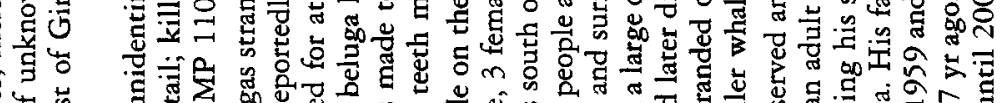

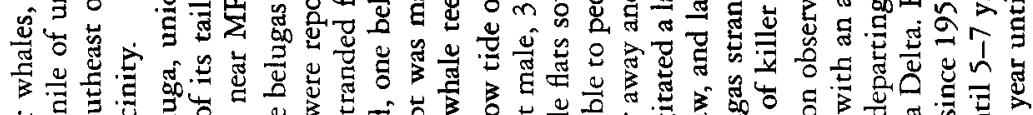

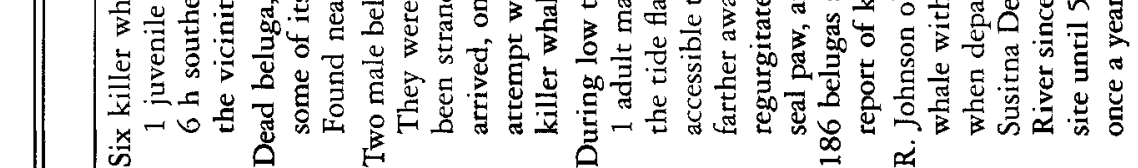

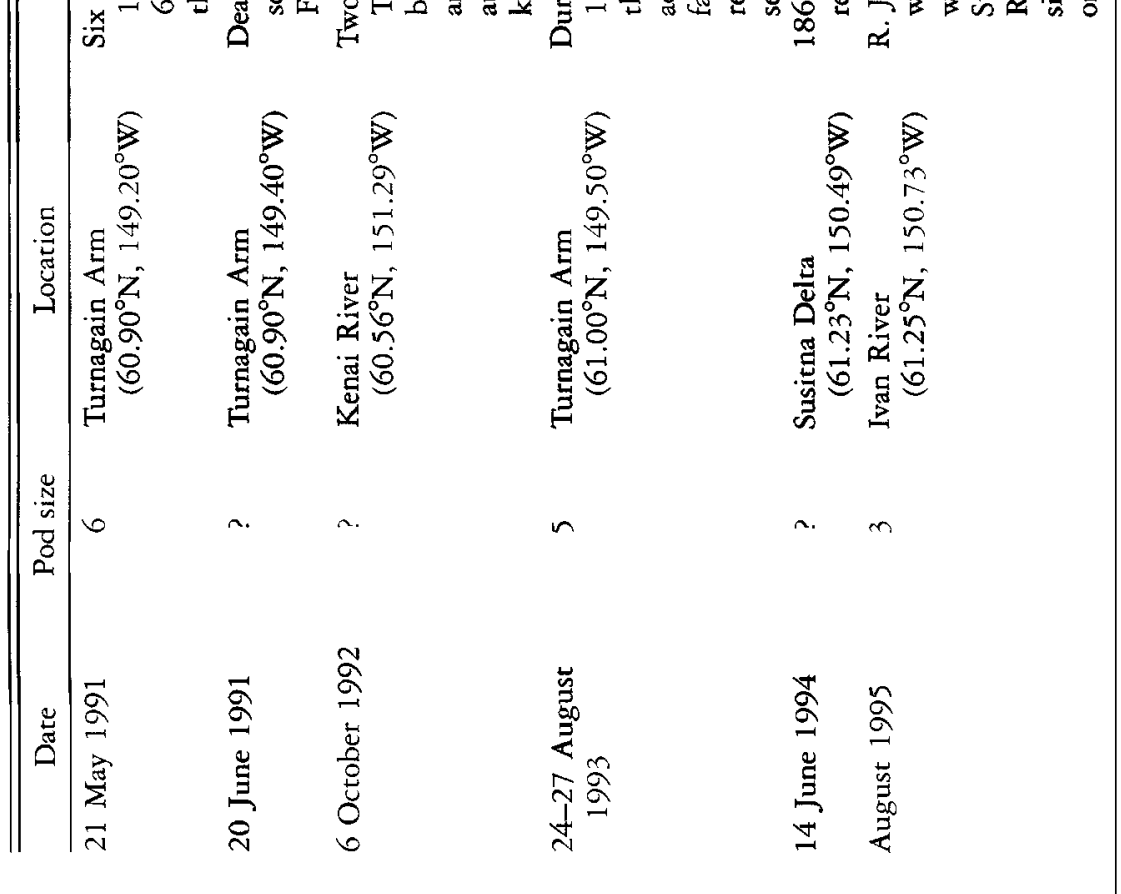




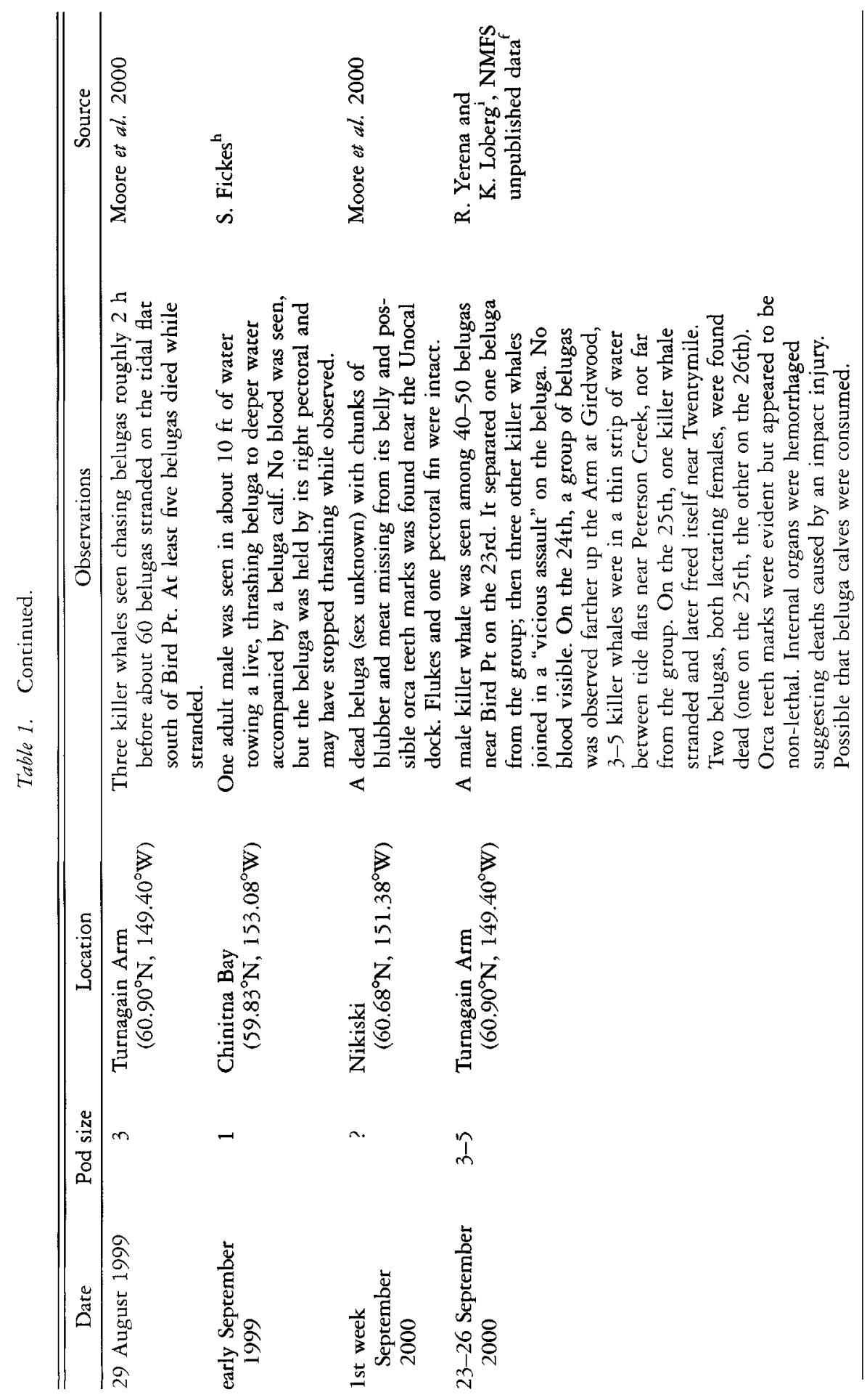




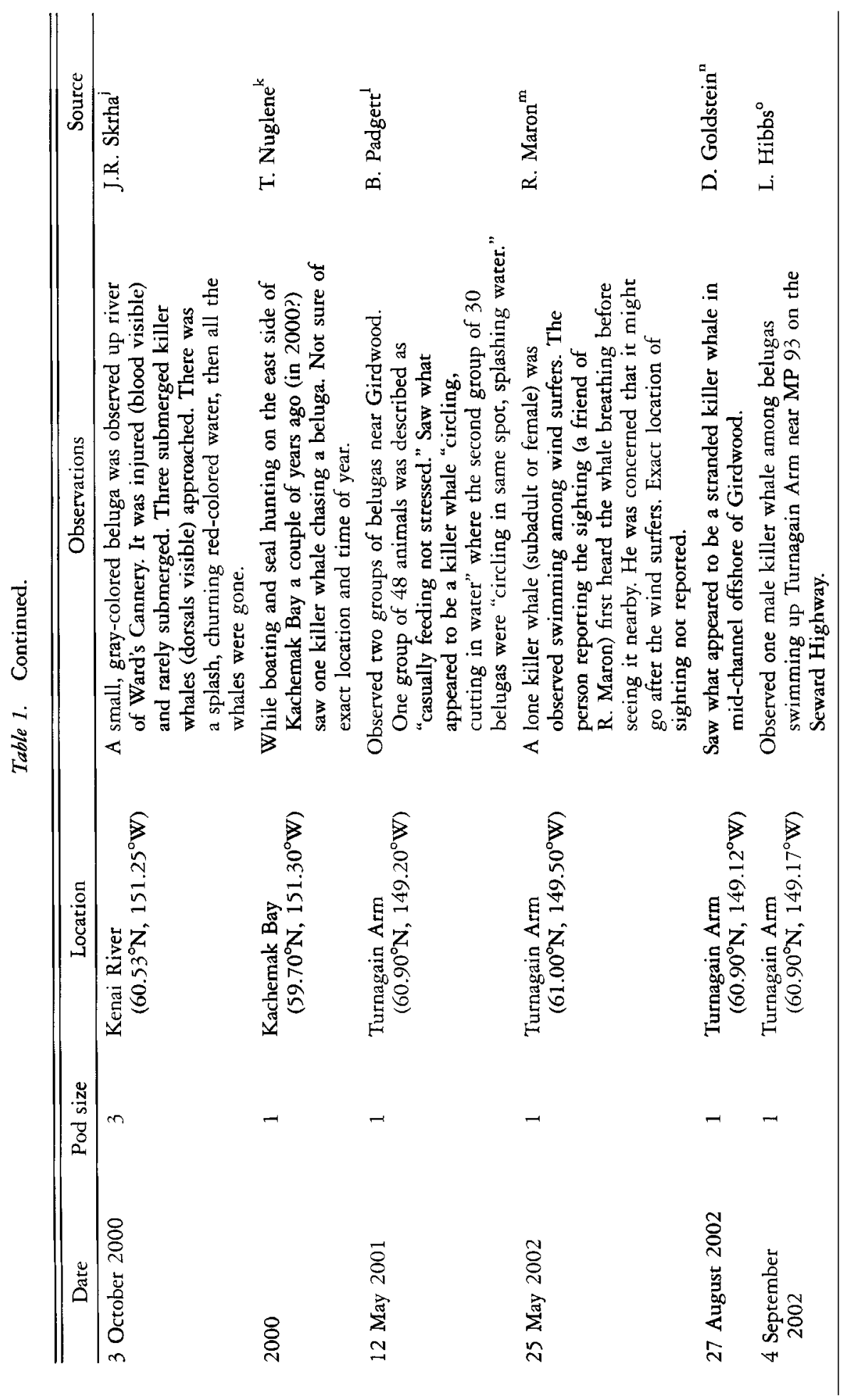




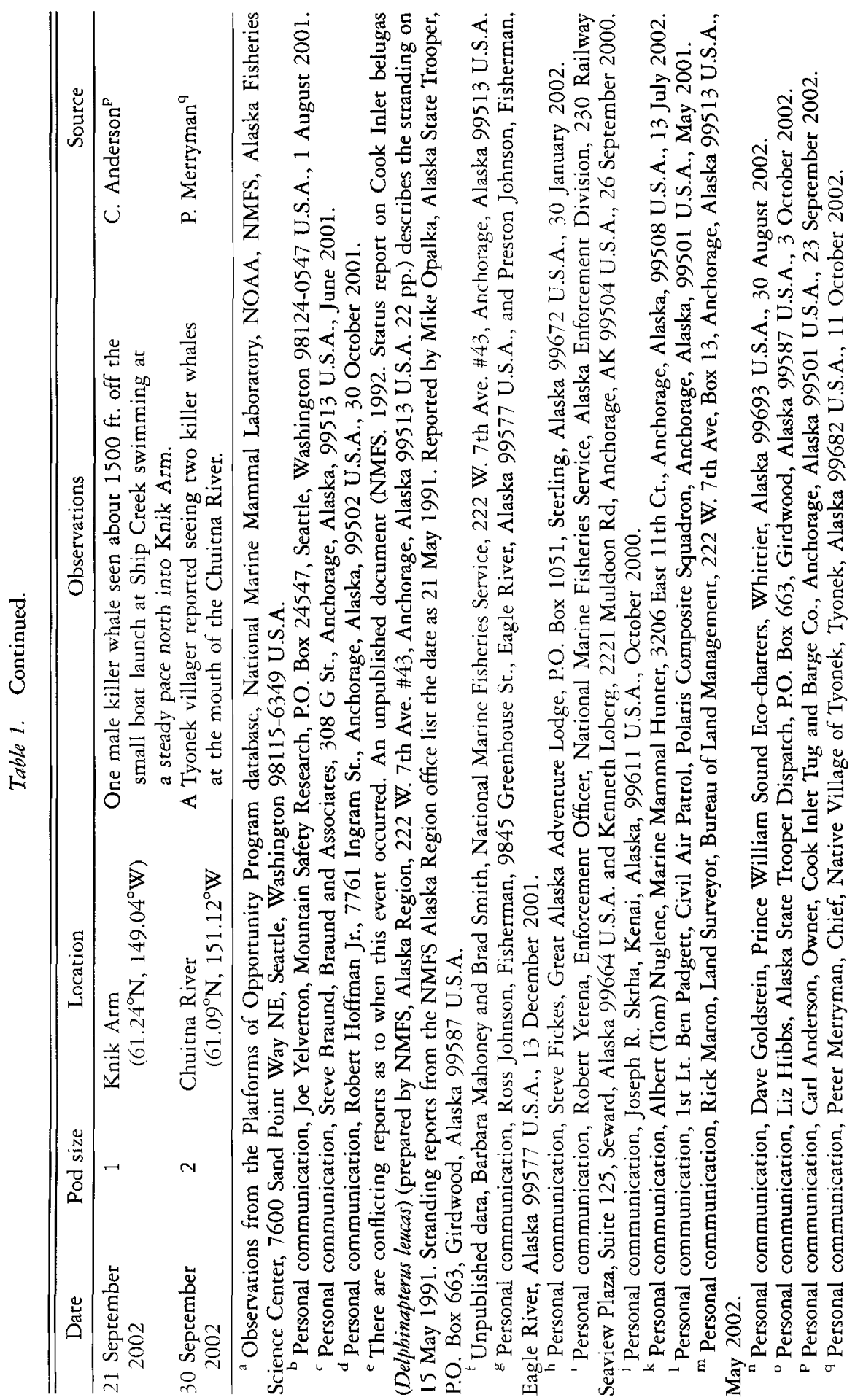


collecting anecdotal accounts. The majority of killer whale sightings in the lower Inlet $(n=75)$ were provided by charter boat operators out of Homer, in Kachemak Bay (Fig. 1).

\section{Number of Killer Whale Sightings}

The number of killer whale accounts $(n=122)$ may be positively biased as there were apparent cases of multiple reports of the same pod seen over several days. For instance, pod ADS was reported six times in Kachemak Bay between late July and mid-September 1998 ( $47 \mathrm{~d}$ ). Of the 122 sightings, 48 occurred within one week of each other and in the same general vicinity $(<40 \mathrm{~km}$ between apparent resightings). None of these sightings could be considered unique based on time and distance between sightings (i.e., apparent swim speed) alone, because all pairwise comparisons of sequential sightings indicate that whales could have easily traveled between the sighting locations at $<2 \mathrm{~km} / \mathrm{h}$. Therefore, it is not evident how many different pods might have entered Cook Inlet.

Since 1985 , there have been 11 confirmed sightings of killer whales with belugas, one unconfirmed sighting (in 1994), and evidence of three other encounters (i.e., two stranded belugas with teeth marks and a killer whale regurgitating beluga flesh) in the waters of Cook Inlet (Table 1).

\section{Pod Size and Identity}

Pod sizes of killer whales observed in the lower Inlet ranged from 1 to 40 animals and included both transient and resident whales. For example, one pod identified in Kachemak Bay was AD5, a pod of 17 resident whales most often observed in the Kenai Fjords region (Matkin et al. 1999). The smallest resident pod in the lower Inlet consisted of five individuals (perhaps only a portion of the AD5 pod). In the upper Inlet pods ranged in size from one to six animals (Table 1). The consistently small size of these pods in the upper Inlet, their interactions with other marine mammals, as well as photographs of pod members with pointed dorsal fins and closed saddle patches, suggests they were transients (Baird and Dill 1996, Baird 2000, Saulitis et al. 2000).

Photographs taken of killer whales that stranded in Turnagain Arm in 1991 (six whales), 1993 (five whales), and 2000 (three-five whales) (Table 1) provided one match of an adult male in 1991 and 1993. Poor quality of additional photographs hindered the ability to identify other individuals, but it does appear that the composition of the killer whale pod during these three encounters was similar. No matches were found between the images of killer whales in Turnagain Arm and those in all available catalogs for Alaska south to Mexico.

\section{Location}

Most killer whale sightings in Cook Inlet occurred in the lower Inlet, despite the strong bias towards reports from high-traffic areas, such as near Anchorage. Of the 122 reported sightings, $81 \%$ were south of $60^{\circ} 33^{\prime} \mathrm{N}$. In the upper Inlet there were only 18 sightings of killer whales in the past $27 \mathrm{yr}$, plus two reports of dead belugas

\footnotetext{
${ }^{7}$ Personal communication from David Ellifrit, Center for Whale Research, 1359 Smuggler's Cove Road, Friday Harbor, WA 98250, 1 May 2002.
} 
with killer whale rake marks (Fig. 1, Table 1). People who have fished the upper Inlet for $20-50 \mathrm{yr}^{8}$ reported few if any sightings of killer whales, and nearly all of these were in the 1990s. In his study of traditional ecological knowledge, Huntington (2000) interviewed Alaska native beluga hunters who reported that killer whales were rarely seen in the upper Inlet or near belugas.

Of the sightings in the lower Inlet, $90 \%$ were east of $152^{\circ} 15^{\prime} \mathrm{W}$, near the Kenai Peninsula. This sighting distribution is biased upward by the high amount of tourist and fishing activity on the east side of the Inlet, especially near Homer, thereby increasing the probability of sightings being reported.

\section{Timing}

Sighting rates through the seasons seem to be correlated with increased traffic: only one sighting was reported from lower Cook Inlet from December to January; only 2-8 sightings per month were reported for February, March, April, and October; whereas 12-24 per month were reported from May through September when more boats may have been on the water. All of the upper Inlet sightings occurred from May through September and were spread fairly evenly (about three sightings per month) through this period. This could either be a function of reduced search effort between fall and early spring, or it could, in part, represent killer whale seasonal occurrence. Sea ice is usually present between November and April (Mulherin et al. 2001), a period which correlates with reduced observational opportunities and, thus, the absence of sightings in the upper Inlet.

Only two sightings were recorded in the upper Inlet prior to 1990 , but since then sightings have been more frequent. Some people have said killer whales were seen at least once a year in upper Cook Inlet since the mid-1990s."

\section{DISCUSSION}

This study of belugas and killer whales in Cook Inlet parallels reports by Lowry et al. (1987) and Frost et al. (1992) from the southeastern Bering Sea, particularly Bristol Bay. Bristol Bay is separated from Cook Inler by the Alaska Peninsula, and similar to Cook Inlet, belugas regularly feed on fish in river mouths over shallow mudflats - areas sometimes invaded by killer whales.

Strandings of belugas and killer whales on these mudflats appear to be associated with these attacks. Killer whales have stranded at least four times in Turnagain Arm (21 May 1991, 24-27 August 1993, 25 September 2000, and 27 August 2002; Table 1), and strandings of killer whales have also been reported elsewhere, such as in Bristol Bay (Lowry et al. 1987, Frost et al. 1992). Only once did a stranding in Cook Inlet result in a known death (Table 1).

Beluga deaths during strandings appear to be rare, seen during only 4 of 14 documented events (total known mortalities $=12$ belugas out of 650 belugas that have been seen stranded since 1988, Moore et al. 2000). Five of these deaths occurred during one event when killer whales were present (29 Aug 1999, Table 1).

\footnotetext{
"Personal communications from Steve Braund, $308 \mathrm{G}$ St., Anchorage, AK 99510 , June 2001; David Ring, 5033 W 80th Ave, Anchorage, AK 99502, 14 June 2001; Nancy Lord, P. O. Box 558, Homer, AK 99603, 12 July 2001; Dan Billman, 13740 McDonell Road, Anchorage, AK 99516, 12 July 2001; and Ross Johnson, 9845 Grecnhouse St., AK 99577, 13 December 2001.

"Personal communication from Preston Johnson, Eagle River, AK 99577, 13 December 2001.
} 
There were no recorded sightings of killer whales in upper Cook Inlet in the 1970 s and only two in the 1980s. However, from 1990 to 2002 there were 18 records of occurrence. In the lower Inlet sightings increased by similar proportions: 14 prior to 1990 to 88 after 1990 , a six-fold increase. This is probably a function of observational effort: it is likely that most whales were missed prior to the $1990 \mathrm{~s}$ when there were fewer observers and no formal network for reporting sightings (the anecdotal reports collected by NMFS in Cook Inlet began in 1988). Current sighting networks are so wide, and interest among the public is so high, that relatively few killer whale occurrences near traffic centers go unreported, especially when there are encounters with belugas. Encounters in the upper Inlet (and in more recent times) are more likely to be reported because there is road access along much of the northeast portion of Cook Inlet, boat traffic is common in the upper Inlet, and there are many sightseers in low-flying aircraft based out of Anchorage.

The documented change in beluga distribution between the 1970s and 1990s (Rugh et al. 2000) has resulted in fewer belugas in the lower Inlet in recent years. Consequently, when killer whales could no longer find belugas in the lower Inlet, they might have increased their visits to the upper Inlet, in spite of the hazards of shallow tidal areas, rapid currents, and seasonal sea ice.

Killer whale predation on Steller sea lions (Eumetopias jubatus) and harbor seals (Phoca vitulina) may have provided these whales with a reliable food source (Corkeron and Connor 1999), given the large numbers of these pinnipeds prior to the 1980s and their predictable use of haul-out sites (Braham et al. 1980, Loughlin et al. 1984). However, declines in abundance of sea lions (Loughlin et al. 1992) and harbor seals (Frost et al. 1994) in Alaska to less than one-half of their original numbers may have forced killer whales to search for alternate food sources in recent years. This possible switch in prey base correlates with the apparent rise in killer whale encounters in upper Cook Inlet (reported here) and in Bristol Bay (Frost $e t$ al. 1992), as well as the increased take of sea otters, Enbydra lutris (Estes tt al. 1998, Hatfield et al. 1998). Of the 54 transient whales identified in the Gulf of Alaska, it is likely that very few visit the upper Inlet and pursue belugas. ${ }^{10}$ However, Estes et al. (1998) calculated that the entire sea otter decline observed recently over large areas in western Alaska could have been caused by less than four killer whales. The relatively smaller area of Cook Inlet and the low number of belugas involved makes it plausible that only a small number of killer whales could be responsible for all of the predation of belugas there.

Killer whales in upper Cook Inlet were probably members of a transient pod. Of the 15 observed interactions, 11 included reports of beluga injuries or mortalities. On every occasion when killer whales were seen in Turnagain Arm, belugas were chased, stranded, consumed, or later found dead. There have been at least 11 observed beluga deaths (i.e., stranded animals that died $(n=5)$ or carcasses found with rake marks $(n=6)$ ) caused by killer whales in the upper Inlet between 1991 and 2000, eight of which occurred in Turnagain Arm.

The most recent observed deaths (23-26 September 2000; Table 1) were of two lactating belugas in Turnagain Arm. Neither of the females were eaten, instead only parts of their flippers or flukes were missing, there were large rake marks across their backs, and death seemed to have been caused by extensive internal hemorrhaging. The lack of any other remains led to the speculation that their calves were consumed. One other sighting in early September 1999 in Chinitna

${ }^{10}$ Personal communication from Jim Diehl, Girdwood, AK 99587, 20 October 2000. 
Bay, also involved a killer whale attacking an adult beluga with a beluga calf present. The killer whale was seen towing the adult beluga by its flipper into deeper water (Table 1). The final outcome was not observed.

Given the current knowledge, the overall contribution of killer whale predation to beluga mortality (at least one per year) appears small. Of the 47 beluga carcasses found in Cook Inlet since 1988, only six showed probable signs of killer whale predation (Moore et al. 2000). However, it is also likely that killer whale predation rates were underestimated because beluga carcasses sank, were carried out of the Inlet, were consumed entirely, or were too decomposed to determine cause of death.

\section{ACKNOWLEDGMENTS}

We are indebted to the scientists, enforcement agents, operators of charter and fishing boats, aircraft pilots, and members of the general public who, by recording and reporting killer whale sightings in Cook Inlet, made this assessment possible. Christy Sims kindly reviewed Platforms of Opportunity Program forms, extracting killer whale sightings. Janice Waite provided insights through many conversations and a constructive review of the document. We also thank Nancy Friday, Brad Smith, Gary Duker, and James Lee for their helpful comments on earlier versions of this work. Randall Reeves and an anonymous reviewer helped streamline the document.

\section{Liter ature Cited}

Agler, B. A., S. J. Kendall, P. E. Seiser and D. B. Irons. 1995. Estimates of marine bird and sea otter abundance in lower Cook Inlet, Alaska during summer 1993 and winter 1994. U.S. Department of Commerce, NOAA, Outer Continental Shelf Study Minerals Management Service 94-0063. 124 pp. Available from Minerals Management Service, Environmental Studies Section, 949 E. 36 th Ave., Anchorage, Alaska 99508.

BAIN, D. E. 1989. An evaluation of evolutionary processes: Studies of natural selection, dispersal, and cultural evolution in killer whales (Orinus orca). Ph.D. dissertation, University of California, Santa Cruz, CA. 257 pp.

BAIRD, R. W. 2000. The killer whale: Foraging specializations and group hunting. Pages 127-153 in J. Mann, R. C. Connor, P. L. Tyack and H. Whitefield, eds. Cetacean societies: Field studies of dolphins and whales. University of Chicago Press, Chicago, IL.

BAIRD, R. W., AND L. M. Dill. 1996. Ecological and social determinants of group size in transient killer whales. Behavioral Ecology 7:408-416.

BigG, M. A., G. M. Elus, J. K. B. Ford and K. C. Baicomb. 1987. Killer whales: A study of their identification, genealogy, and natural history in British Columbia and Washington State. Phantom Press, Nanaimo, British Columbia, Canada.

Braham, H. W., and M. E. Dahlhfim. 1982. Killer whales in Alaska documented in the Platforms of Opportunity Program. Report of the International Whaling Commission 32:643-646.

Braham, H., R. Everitt and D. Rugh. 1980. Northern sea lion population decline in the Eastern Aleutian Islands. Journal of Wildlife Management 44:25-33.

Calkins, D. G. 1983. Marine mammals of lower Cook Inlet and the potential for impact from Outer Continental Shelf oil and gas exploration, development, and transport. Research Unit 243; Final Report of Principal Investigators. U.S. Department of Commerce, NOAA, Outer Continental Shelf Environmental Assessment Program 20:171-263.

Corkeron, P. J., and R. C. Connor. 1999. Why do baleen whales migrate? Marine Mammal Science 15:1228-1245. 
DAHLHEIM, M. E. 1997. Photographic catalog of killer whales, Orcinus orca, from the central Gulf of Alaska to the southeastern Bering Sea. U.S. Department of Commerce, NOAA Technical Report NMFS-131. 58 pp.

Dahlheim, M. E., and J. E. Heyning. 1998. Killer whale Orcinus orca (Linnaeus, 1758). Pages 281-322 in S. H. Ridgway and R. J. Harrison, eds. Handbook of marine mammals. Volume 6. Academic Press, New York, NY.

Dahlheim, M. E., D. K. Eli.ifrit and J. D. Swenson. 1997. Killer whales of southeast Alaska: A catalogue of photo-identified individuals. Day Moon Press, Seattle, WA. 79 pp.

Dahiheim, M., A. York, R. Towell, J. Waite and J. Breiwick. 2000. Harbor porpoise (Pbocoena phocoena) abundance in Alaska: Bristol Bay to Southeast Alaska, 1991-1993. Marine Mammal Science 16:28-45.

DE LagunA, F. 1975. The archaeology of Cook Inlet, Alaska. 2nd edition. Alaska Historical Society, Anchorage, AK. [Originally published in 1934 by University of Pennsylvania Press, Philadelphia, PA.]

Estes, J. A., M. T. Tinker, T. M. Williams and D. F. Doak. 1998. Killer whale predation on sea otters linking oceanic and nearshore ecosystems. Science 282: $473-476$.

Frost, K. J., R. B. Russell and L. F. Lowry. 1992. Killer whales, Orcinus orca, in the southeastern Bering Sea: Recent sightings and predation on other marine mammals. Marine Mammal Science 8:110-119.

Frost, K. J., L. F. Lowry, E. H. Sinclair, J. Ver Hoef ANd D. C. McAilister. 1994. Impacts on distribution, abundance, and productivity of harbor seals. Pages 97-117 in T.R. Loughlin, ed. The impact of the Exxon Valdez oil spill on marine mammals. Academic Press, New York, NY.

GEORGE, J. C., AND R. SUYDAM. 1998. Observations of killer whale (Orcinus orca) predation in the northeastern Chukchi and western Beaufort Seas. Marine Mammal Science $14: 330-332$.

Goley, P. D., AND J. M. STRAley. 1994. Attack on gray whales (Escbricbtius robustus) in Monterey Bay, California, by killer whales (Orcinus orca) previously identified in Glacier Bay, Alaska. Canadian Journal of Zoology 72:1528-1530.

GUINET, C., AND J. BouviER. 1995. Development of intentional stranding hunting techniques in killer whale (Orcinus orca) calves at Crozet Archipelago. Canadian Journal of Zoology 73:27-33.

HANSEN, D. J., AND J. D. HubBard. 1999. Distribution of Cook Inlet beluga whales (Delphinapterus leucas) in winter. Final Report. Outer Continental Shelf Study, U.S. Department of the Interior, Minerals Management Service, 949 East 36th Ave. Suite 300, Anchorage, Alaska 99508. Rept. 99-0024, v.p.

Hatfield, B. B., D. Marks, M. T. Tinker, K. Nolan and J. Peirce. 1998. Attacks on sea otters by killer whales. Marine Mammal Science 14:888-894.

HeIde-JørGENSEN, M. P. 1988. Occurrence and hunting of killer whales in Greenland. Pages 115-135 in J. Sigurjónsson and S. Leatherwood, eds. North Atlantic killer whales. Journal of the Marine Research Institute, Reykjavík, Vol. XI.

Heyning, J. E., AND M. E. Dahlheim. 1988. Orcinus orca. Mammalian Species Account, American Society of Mammalogists No. 304. 9 pp.

Hobss, R. C., D. J. Rugh AND D. P. Demaster. 2000. Abundance of belugas, Delpbinapterus leucas, in Cook Inlet, Alaska, 1994-2000. Marine Fisheries Review 62(3): $37-45$.

Huntungton, H. P. 2000. Traditional knowledge of the ecology of belugas, Delphinapterus leucas, in Cook Inlet, Alaska. Marine Fisheries Review 62(3):134-140.

KIEIN, J. R. 1981. A history of Kachemak Bay: The country, the communities. Homer Society of Natural History, Homer, AK.

Kieinenberg, S. E., A. V. Yabiokov, V. M. Belkovich and M. N. Tarasevich. 1964. Beluga (Delphinapterus leucas): Investigations of the species. Israel Program for Scientific 
Translations, Jerusalem, 1969. 376 pp. Available from the Department of Commerce, Clearinghouse for Federal Scientific and Technical Information, Springfield, VA.

Leatherwood, S., R. R. Reeves, W. F. Perrin and W. E. Evans. 1982. Whales, dolphins, and porpoises of the Eastern North Pacific and adjacent arctic waters: A guide to their identification. U.S. Department of Commerce, NOAA Technical Report NMFS Circular-444. 245 pp.

Lobdell, J. E. 1980. Prehistoric human populations and resource utilization in Kachemak Bay, Gulf of Alaska. Ph.D. dissertation, University of Tennessee, Knoxville, TN. $291 \mathrm{pp}$.

Loughun, T., D. Rugh AND C. Fiscus. 1984. Northern sea lion distribution and abundance: 1956-80. Journal of Wildlife Management 48:729-740.

Loughlin, T. R., A. S. Perlov and V. A. Vladimirov. 1992. Range-wide survey and estimation of total number of Steller sea lions in 1989. Marine Mammal Science $8: 220-239$.

Lowry, L. F, R. R. Neison And K. J. Frost. 1987. Observations of killer whales, Orcinus orca, in western Alaska: Sightings, strandings, and predation on other marine mammals. Canadian Field-Naturalist 101(1):6-12.

Mahoney, B. A., and K. E. W. Sheiden. 2000. Harvest history of belugas, Delpbinapterus leucas, in Cook Inlet, Alaska. Marine Fisheries Review 62(3):124-133.

Matkin, C., G. Ellis, E. Saulitis, L. Barrett-Lennari and D. Matkin. 1999. Killer whales of southern Alaska. North Gulf Oceanic Society Press, Homer, AK.

Moore, S. E., K. E. W. Shelden, L. K. Litzky, B. A. Mahonfy and D. J. Rugh. 2000. Beluga, Delphinapterus leucas, habitat association in Cook Inlet, Alaska. Marine Fisheries Review 62(3):60-80.

Mulherin, N. D., W. B. Tucker III, O. P. Smith ANd W. J. Lee. 2001. Marine ice atlas for Cook Inlet, Alaska. U.S. Army Engineer Research and Development Center, Cold Regions Research and Engineering Laboratory, 72 Lyme Road, Hanover, New Hampshire. ERDC/CRREL TR-01-10. 147 pp.

NMFS. 2000. Designating the Cook Inlet, Alaska, stock of beluga whale as depleted under the Marine Mammal Protection Act (MMPA). Final rule. USA Federal Register 65(105):34590-34597.

O'Corry-Crowe, G. M., R. S. Suydam, A. Rosenberg, K. J. Frost and A. E. Dizon. 1997. Phylogeography, population structure and dispersal patterns of the beluga whale Delphinapterus leucas in the western Nearctic revealed by mitochondrial DNA. Molecular Ecology 6:955-970.

OsGOOD, C. 1937. The ethnography of the Tanaina. Yale University Press, New Haven, CT.

Reeves, R. R., AND E. Mitchfll. 1988. Distribution and seasonality of killer whales in the eastern Canadian Arctic. Rit Fiskideildar 11:136-160.

Rugh, D. J., K. E. W. Shelden and B. A. Mahoney. 2000. Distribution of belugas, Delphinapterus leucas, in Cook Inlet, Alaska, during June/July, 1993-2000. Marine Fisheries Review 62(3):6-21.

Saulitis, E., C. Matkin, L. Barrett-Lennard, K. Heise and G. Ellis. 2000. Foraging strategies of sympatric killer whale (Orinus orca) populations in Prince William Sound, Alaska. Marine Mammal Science 16:94-109.

Sergeant, D. E., and P. F. Brodie. 1969. Body size in white whales, Delpbinapterus leucas. Journal of the Fisheries Research Board of Canada 26:2561-2580.

SLePTSOv, M. M. 1952. Whales of the far eastern seas. Izv. TINRO 38 [in Russian, cited in Kleinenberg et al. 1964].

Speckman, S. G., and J. F. Piatt. 2000. Historic and current use of lower Cook Inlet, Alaska, by belugas, Delphinapterus leucas. Marine Fisheries Review 62(3):22-26.

Tomilrs, A. G. 1957. Cetacea. Volume 9 in V. G. Hepener, ed. Mammals of the U.S.S.R. and adjacent countries. Israel Program for Scientific Translations, Jerusalem, 1967.717 pp.

Received: 24 May 2002

Accepted: 28 October 2002 